\title{
REVIEW
}

\section{Docs for docs: Online with the NFB}

\author{
A longer version of this article was previously published at www.cmaj.ca
}

$\mathrm{T}$ he National Film Board of Canada has opened a "screening room" online, where viewers can catch, free of charge, more than 600 of the 13000 or so films the institution has produced over its 70 year history. More are being added by the month, ranging from arty little animations to feature-length documentaries, some of which might be of special interest to medical professionals.

One of the gems in the collection is Bethune, Donald Brittain's elegant 1964 documentary on Canada's original doctor without borders, Norman Bethune - medical innovator, artist, adventurer, poet, bon vivant, communist, secular saint. ${ }^{1}$ The film blends archival film footage and photographs, interviews with friends and contemporaries, and some plummy narration by Lister Sinclair.

If there is a contemporary equivalent of Norman Bethune, it might be James Orbinski, a Toronto physician and past president of Doctors without Borders. In Patrick Reed's 2007 documentary, Triage: Dr. James Orbinski's Humanitarian Dilemma, we witness Orbinski's struggle to channel the rage he feels when confronted with the carnage inflicted on innocent people in modern war zones. ${ }^{2}$ Unfortunately, only short excerpts from the film are currently available on the NFB site.

Director Ian McLeod's documentary House Calls (2004) examines the concerns of another physician/advocate, Toronto's Mark Nowaczynski, who photographs his vulnerable, elderly patients in their own homes to draw attention to a lack of available home care services. ${ }^{3}$ The film moves at about the pace of its elderly subjects, which perhaps lends it a certain dignity, but makes for less than riveting viewing.

In the medical curio category is an

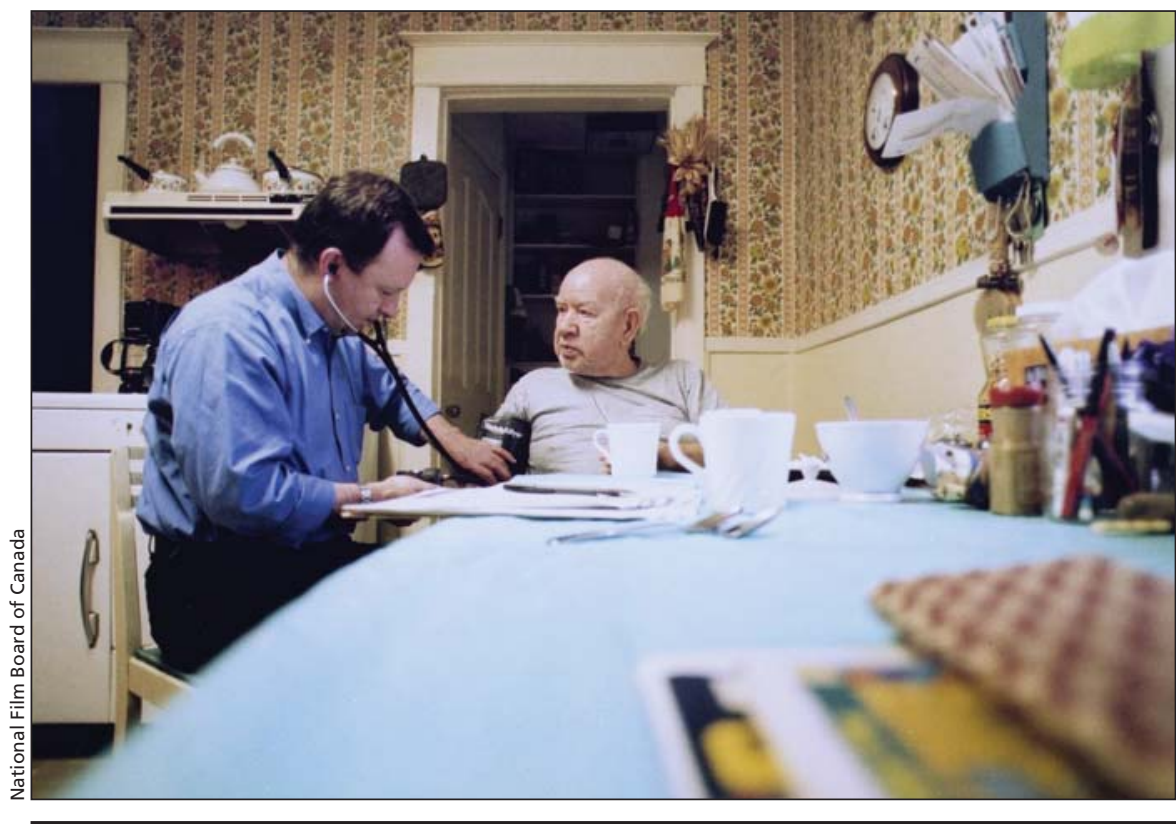

In House Calls (2004), Joe gets a check-up from Dr. Mark Nowaczynski, who photographs his vulnerable, elderly patients to draw attention to the lack of home care services.

episode from film No. 40 in the NFB's Eye Witness series, a collection of short, newsreel-style productions from the 1940s and 1950s. Modern Miracle: Surgery is Safe follows apocryphal patient Henry Brown through an appendectomy.

Another theme that gets a workout in the NFB catalogue is the unintended consequences of Western affluence on the human body. For the first time in history, more people are dying of overnutrition than undernutrition. Glynis Whiting's 2003 documentary The Weight of the World, produced by NFB and the CBC's The Nature of Things, in partnership with the Heart and Stroke Foundation of Canada and Physical and Health Education Canada, is a lively examination of that expanding reality.

David Suzuki narrates, as experts from Canada, Sweden, the Nether- lands and elsewhere point fingers at the usual suspects: supersized meals and the megasized advertising budgets that promote them, urban sprawl and sedentary occupations. The result is about 300 million obese adults in the world, 100 million of them in developing countries.

Accompanying the hour-long film is a number of mini-docs examining, among other topics, the measures taken by the residents of Sandy Lake, Manitoba, a First Nations community with the unenviable distinction of having the third-highest rate of type 2 diabetes of any subpopulation in the world, to regain the health of the community.

In the plus ça change category, Wolf Koenig's 1960 short, I Was a Ninetypound Weakling, takes a slightly tongue-in-cheek look at the struggles of some Montréalers to control their weight and stay fit in an age of ease and 
abundance - or at least what passed for ease and abundance a half century ago, before we got really good at it.

An interesting companion piece is Shredded, a 2005 documentary by Richard Gaudio and Douglas C. Taplin, which suggests that the flabbier we've allowed our bodies to get, the more obsessive we've become about them. Here we meet a group of teenage males obsessed with transforming as much of their body fat as possible into Popeye arms and six-pack abs. Gradually, it dawns on these gym rats that the only way to achieve their Schwarzeneggerian ideal is with the aid of black market pharmaceuticals.

There is a similar dilemma at the heart of Ann Shin's Western Eyes (2000), a documentary about two young Asian-Canadian women contemplating cosmetic surgery as a way to blend in better in a Eurocentric society. The participants proclaim, "I want to get it done because I want to feel better." Ultimately, Sharon, a KoreanCanadian, undergoes a barely discernible Westernization of her eyelids. Afterward, she notes an improvement in her confidence, while at the same time acknowledging the destructive aspects of her own narcissism. Shin recognizes the fundamental pain behind it all, but offers no easy remedies.

Pain, some of it almost unbearable to witness, is also at the centre of a number of NFB documentaries concerning alcohol and drug abuse. Gil Cardinal's Children of Alcohol (1984) follows a group of adolescents on a horseback trip in the Rockies, where they discuss the impact on their lives of their parents' drinking. The horses and the scenery are distracting, but the kids are articulate and insightful beyond their years.

Janice Brown's documentary, The Agony of Jimmy Quinlan (1978), is the story of a homeless Montréal man - he's 38 but looks a hard 60 - who had been drinking up to 10 bottles of cheap sherry a day for 12 years before deciding to go cold turkey. If getting off the bottle isn't physiologically daunting enough, Jimmy must also face the prospect of becoming a pariah in the only world he knows. To his street friends, sobriety is the ultimate in betrayal and repudiation.

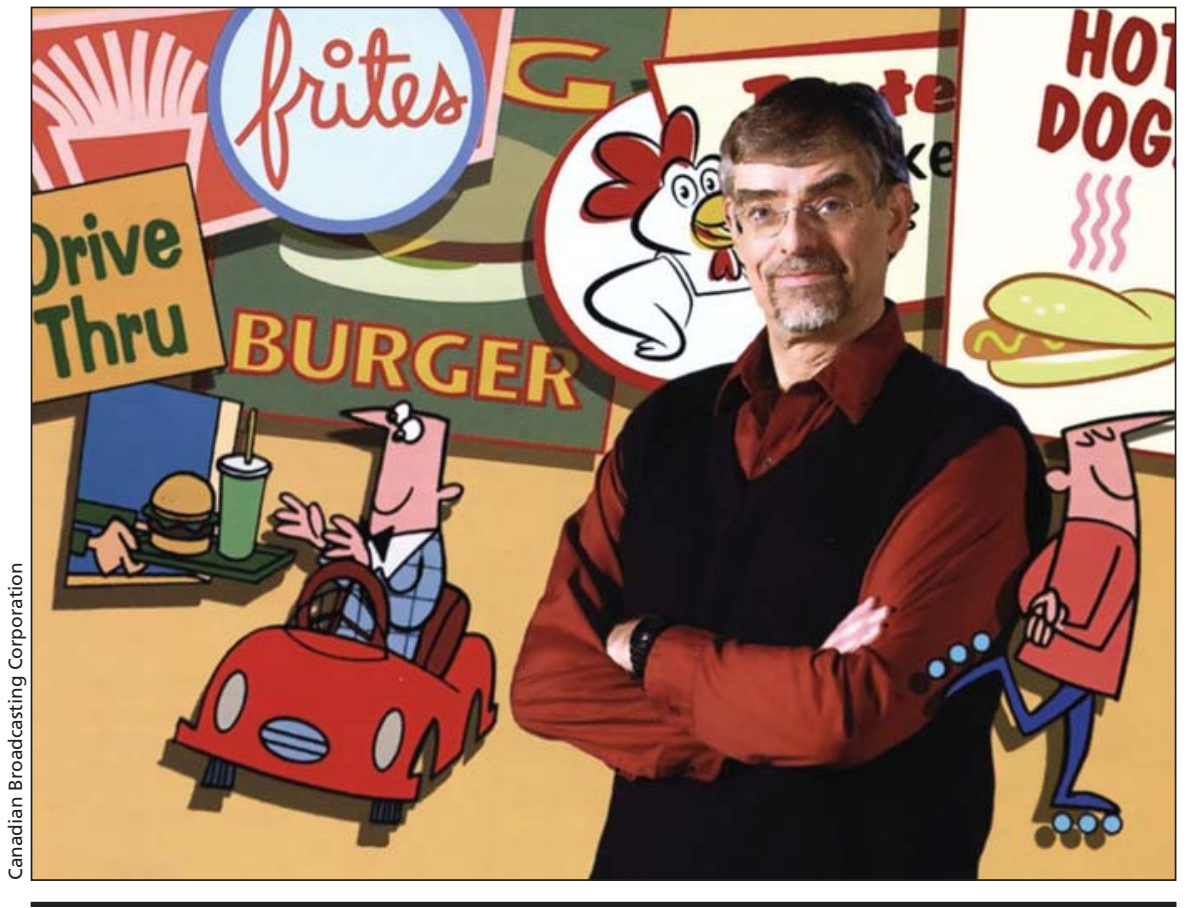

The supersized documentary, The Weight of the World (2003), looks at everything from megasized advertising budgets to garage-door openers, to explain the current obesity epidemic.

Viewed back to back, a pair of documentaries about efforts to police Vancouver's street drug scene offers a fascinating reminder of the intractability of the problem - at least in our chosen approaches to it. Whistling Smith (1975), directed by Michael Scott and Marrin Canell, is a portrait of an edgy street cop, Sergeant Bernie "Whistling" Smith, who rules his turf with a hands-on tough love unlikely to satisfy civil libertarians, addiction treatment professionals or nervous police chiefs. Smith brags of a 57 per cent drop in crime on his beat, but it's mostly achieved by insisting that those he views as potential criminals take their act somewhere else, presumably into some other cop's jurisdiction.

Fast forward a quarter century. The kindly police officers in Veronica Alice Mannix's Through a Blue Lens (1999) patrol the streets of Vancouver's Downtown Eastside, even sadder now than in Whistling Smith's day. They are armed not only with nightsticks, but with video cameras they used to document the lives of the regulars on their beat. They hope the misery they capture on tape can be used to help dissuade others from ending up here - a dubious assumption at best.
While police strategies over the years have evolved from strong-armed enforcement to compassionate containment, none appears to have had the slightest impact on the demand for heroin and other drugs we deem criminal. Perhaps, as these films suggest, it's because we've saddled law enforcement personnel with the responsibility of managing what remains fundamentally a public health problem.

\section{David McDonald}

Writer and filmmaker Ottawa, Ont.

\section{REFERENCES}

1. Howard AW. Bethune: consummate humanitarian and man of action. CMAJ 2009;180:1334.

2. Sibbald B. Human being. CMAJ 2008;178:1191-2.

3. Brett-McLean P. The elderly patient: in situ. CMAJ 2007; 175(11):1617

Get your free ticket to the National Film Board of Canada viewing room at www.nfb.ca/

David McDonald's most recent documentary, Cereal Thriller, is about the unintended consequences of a 1955 cereal-box promotion. 